ISBN 978-93-86878-30-4

14th PORTO - PORTUGAL International Conference on Humanities, Social Sciences and Education

(PHSSE-19)

Porto (Portugal) Sept.9-11, 2019

\title{
Emotional Synchrony of the Narrator and Readers in Villette
}

\author{
Reiko Yamamoto ${ }^{1}$ \\ ${ }^{1}$ Department of English Studies for Careers, Kyoto Junior College of Foreign Studies, Kyoto.
}

\begin{abstract}
The aim of this study is to reveal how emotional synchrony between a narrator and readers is created. In "Villette", by Charlotte Brontë, the stream of the narrator's consciousness often goes ahead that of the young heroine's, causing the narration to become distorted and, in a sense, unjust and insincere to readers. However, contrary to practical wisdom, such premature narrative succeeds in drawing readers into an emotional synchrony with the narrator. Emotional synchrony in the novel occurs in three configurations: between young Lucy and old Lucy (the narrator who is recollecting the past), young Lucy and the readers, and old Lucy and the readers. The blending of the three can make the novel seem too complicated and chaotic. Ultimately, however, this characteristic is not a failure but an unrecognized means of defiance, exposing the narrator's inner emotions and true feelings and allowing readers to unconsciously emotionally synchronize with the narrator.
\end{abstract}

Keywords: narrative, emotional synchrony, the implied author

\section{Introduction}

Movement synchrony observed in oral interaction has been the target of research [1] [2]. The automatic and unconsciously embodied simulation of another's actions, intensions, and emotions is due to neuronal mechanisms, and the embodied simulation constitutes a fundamental and functional mechanism for empathy and understanding another person's mind [3]. At the same time, as [4] points out, researchers have focused on the relationship between language and emotion over the last decades. All major human emotions can be reported in their narratives [5]. With the consideration above, this study focuses on emotional synchrony of the narrator and readers in a masterpiece of literature.

Repeatedly, all major human emotions can be reported in narratives [5]. What makes the novel Villette [6] distinctive is its narration. Its narrator is Lucy Snowe, whom we find difficult to understand at first. She appears calm and cool, so she does not attract us. Nevertheless, as we gradually come to understand Lucy Snowe, we find her more attractive than any other heroine in Charlotte Brontë's novels. Charlotte Brontë gave an unhappy ending only to the heroine of her last novel, Villette, and presents a theme different from that of her other novels. Lucy overcoming her struggles does not show us the theme of the novel, but the narration of the novel does.

Villette is presented in first-person narration, as Lucy recollects her own experiences of about thirty years ago. She always addresses 'the implied reader'. The elation of the narrator and readers in this novel is closer than in any other Brontë novel. Through its peculiar narration, Charlotte Brontë presents the reality of the human mind as its main theme. Certainly, the independence of women is also a theme, which Brontë reflects in the stream of the heroine's consciousness here, as in her other novels.

Her famed masterpieces, Jane Eyre or Shirley, are based on Brontë's own experiences from her youth, but what she tries to describe in Villette seems to be more than that. She would not have chosen to recycle the same materials as she used in her first novel, The Professor, if she had not intended to develop the theme differently. Both The Professor and Villette are based on the same experiences. When she was in Brussels, she fell in love 
with her teacher, M. Hager, who had a wife and children. She reproduced this bitter experience in The Professor, but gave the couple a happy ending, which is not the case in her final novel. The title Villette also shows Brontë's intention to take a more objective view of the heroine. It is more appropriate to analyse Villette not as an autobiography, but as a fictional work independent of Brontë's real life. Though previous researchers have tried to analyse how Charlotte Brontë reflected herself in the narrator, the target of this study is to clarify how she liberated the narrator's spirit.

\section{Narrative-communication}

The introduction to the first chapter plainly shows that the story is a first-person narrative. However, the style of the narration is not emotive.

My grandmother lived in a handsome house in the clean and ancient town of Bretton. Her husband ... whether by coincidence, or because some remote ancestor had been a personage of sufficient importance to leave his name to his neighbourhood, I know not. (Ch. 1, p. 61)

The narrator ignores the general rule of introductions: to interest readers. Moreover, nothing is explained about 'I' here; however, many details are provided about other characters. Through such expressions as 'I know not', readers might feel that the narrator speaks with some detachment. It seems that the narrator certainly has her own feelings but hides them for some reason.

Notably, the time of the narration is significant. The old narrator tells readers what she herself experienced about thirty years ago. Thus, she is quite similar to a third-person omniscient narrator in the sense that she knows all that happened within the story. There are two kinds of omniscience, third-person omniscience and thirdperson limited omniscience [7][8]. As her narration shares certain similarities with the latter, it could be called first-person limited omniscience. Although the narrator resembles a third-person omniscient narrator, she does not need to be as authoritative as one.

According to [9], narrative-communication is realized as in Fig. 1.

$$
\text { Real author } \rightarrow \text { Implied author } \rightarrow \text { Narrator } \rightarrow \text { Narratee } \rightarrow \text { Implied reader } \rightarrow \text { Real reader }
$$

Fig. 1: The narrative-communication path

In order to clarify the features of narration, only the part inside the grey box will be targeted in this paper, because it inheres in narrative.

\section{The relationship of the narrator and the narratee}

In Villette, the relationship between the narrator and the narratee is quite strong. The narrator deliberately cultivates this relationship. She continually addresses the implied readers, emphasising that she is sharing a recollection by repeating 'Reader', 'My readers', 'You should have seen...' (Ch. 27, p. 407). As a result, the real readers are kept from entering the young heroine's world. They are obliged to maintain an awareness that the narrator is speaking and that there is a distance between the young heroine and themselves. There are many interjections which emphasize the existence of the narrator: 'I shall go on with this part of my tale' (Ch. 7, p. 128), 'I might just now, instead of writing this heretic narrative, be counting ...' (Ch. 15, p. 235). In addition to these expressions, the narrator uses the phrase 'I remember (recollect)' in many places. It continually reminds readers that the story is the narrator's recollection.

Here, the relation between the narrator and narratee will be analysed in-depth. The narratee is assumed and created by the implied author. As the agent of the implied reader, he reacts to the narrative as the narrator expects. In a sense, readers are forced to follow the model of the narratee [10]. Throughout the novel, readers are 
expected to evaluate Lucy's perceptions constantly, for they are often partial or mistaken [11]. In the novel, the implied author has a completely different perspective from the narrator's. The narratee acknowledges Lucy's faults and also anticipates how readers will feel about them. Thus, he ensures that the reactions of the agent (narratee) should not be unnatural or compulsory for readers. Readers can simply project themselves on the narratee.

Some narratees are personified, while others are not [10]. The narratee in Villette is the latter. Regarding the narrative-communication context in Villette, the narratee is, almost exactly, designed as a placeholder for real readers. The narrator addresses the narratee outside of the plot. According to the state of her feelings, however, the narrator draws the narratee into the plot or even makes him share the place of young Lucy.

\section{Features of narrative}

\subsection{Insincerity of the narrator}

Moreover, the narrator insists on her reliability: 'I can assure the reader ...' (Ch. 27, p. 408; Ch. 33, p. 470), 'I do but speak the truth when I say ...' (Ch. 37, p. 533). On the contrary, this pretence to be reliable reveals the narrator's insincerity. Some 'concrete' situations are as follows:

1) The narrator conceals from readers till Ch. 16 that young Lucy knew that John was Graham (Ch. 10).

2) The narrator does not confess that Lucy was making a watch guard for Paul and was favourably disposed toward him (Ch. 27-29).

3) The narrator gives hints to readers, but never explicitly states, what became of Paul in a heavy storm (Ch. 42).

For what purpose is the narrator so unreliable? The main stream of the novel is the process of young Lucy's growth. In the end, her mind's growth is ideally accomplished. Old Lucy now, consequently, should be an independent woman who had a truly strong mind, but in fact, old Lucy the narrator still has an immature mind. Her narration occasionally shows the same weaknesses as young Lucy had. Young Lucy feared that her love for Paul or John would never be rewarded. Therefore, she depended on cold 'reason' and tried not to be aware of the love she felt. Old Lucy still cannot overcome the fear and still unconsciously hides the love from readers [11]. Thus, inevitably, she must be an insincere narrator in spite of her efforts to be reliable.

Indeed, human feelings intervene in old Lucy's narration in innumerous places. The greater old Lucy's emotional synchrony with young Lucy becomes, the less reliable her narration becomes, and old Lucy's words seem to gush out more freely from her heart. At first, as in the introductory passage quoted in the first page, old Lucy calmly narrates how young Lucy lived passively as an observer. She, however, gradually becomes more emotional, in parallel with the young Lucy in her narrative. Young Lucy grows to use the present tense more often and draws readers into the narrative [12]. Readers experience the gradual change as something quite remarkable, because old Lucy emphasized at the beginning that her narrative was just recollection. In the end, the narrator begins to use the word 'we' and reaches the ultimate situation: she assimilates readers with Lucy [12]. As the end of the novel approaches, such scenes appear more often. Toward the end of the novel, young Lucy cannot endure her severe life and begins to disclose what she has tried to hide: Passion and feelings.

\subsection{Uncertainty in tenses}

When she is narrating her unforgettable agonies, old Lucy also cannot keep her composure: 'The wind shifts to the west. Peace, peace, Banshee-"keening" at every window!' (Ch. 42). Here, then, she narrates in the present tense. However, in next paragraph, she changes to past tense again: 'That storm roared frenzied for seven days'. This shows that old Lucy now takes a clear-cut attitude toward the past and has recovered her calmness in her grown mind. This calmness, however, soon proves to be different from that described in the opening passage of Ch. 1. Now, she uses the word 'they' and speaks to readers with perfect detachment: 'Here pause. Pause at once. There is enough said. ... Madame Walravens fulfilled her ninetieth year before she died. Farewell' (Ch. 42). In the end, she becomes an utterly unreliable narrator and never informs readers of Paul's fate. Old Lucy 
conceals the truth, which proves that she has not yet recovered from her sorrow and agony. Apparently young Lucy symbolizes the weakness of human mind, but the very nature of old Lucy's narration about young Lucy much more effectually contributes to the theme of the novel - humanity or human weakness.

\subsection{Breaking situation}

Here, the paper analyses how the situation is sometimes broken. In one exceptional case, young Lucy presents an interior dialogue: 'Courage, Lucy Snowe! With self-denial and economy now, and steady exertion by-and-by, an object in life need not fail you ...' (Ch. 31, p. 450). It is noticeable that old Lucy's feelings never intervene in these dialogues. Though it is true that old Lucy narrates, but what old Lucy narrates is, readers feel, exactly what young Lucy thought. It is against the basic conventions of narrative-communication; the narrator's voice is not heard in those dialogues. There is no implied reader. Thus, real readers feel as if they are listening to young Lucy's voice directly. In the interior dialogues, readers feel young Lucy's strong feelings and passion more keenly than in other parts of the narrative. It is the effect of interior dialogues.

The narrative presented in interior dialogues, especially those conducted by a sensible person, are usually contradictory or difficult to understand. This is because the communicative situation in these interior dialogues is extraordinary or even contrary to the fundamental conditions established by the overall narrative, as readers notice. Therefore, readers expect the narrator to help them understand the narrative when young Lucy's feelings become unsympathetic. Since readers are indeed helped by the narrator, they might sense that they need not be suspicious of what they read. The implied author also assumes readers' attitudes and can freely describe young Lucy's feelings without modification. Though young Lucy sometimes seems too passionate, sometimes too sensitive, and sometimes even crazy, readers are receptive to understanding young Lucy through old Lucy's narration.

\subsection{Differences between the three narrative perspectives}

In order to clarify what the implied author intends by changing from young Lucy's to old Lucy's perspective and vice versa, narratives by the implied author, the narrator (old Lucy), and young Lucy are compared in Table 1 and Table 2.

Young Lucy's column lists the main events which young Lucy experiences. The narrator's column lists characteristics of her narration: how she modifies the events, how she conceals the truth, and how she changes the tenses or communicative situation. Also, what the implied author intends to accomplish through such narration is clarified in the implied author's column. The underlined parts represent steps within young Lucy's mental growth. Table 1 and Table 2 reveal that the techniques described in the three columns are mutually support the author's work-out scheme. 
TABLE I: A Comparison of the Implied Author, the Narrator, and Young Lucy.

\begin{tabular}{|c|c|c|c|}
\hline the implied atuhtor & the narrator (old Lucy) & Ch. & young Lucy \\
\hline & $\begin{array}{l}\text { empathises the recollection and her } \\
\text { reliability }\end{array}$ & $1-3$ & a calm observer \\
\hline & & & a passive life with Miss Marchmont \\
\hline & $\begin{array}{l}\text { tells that she is now a snow-haired old } \\
\text { woman }\end{array}$ & 5 & goes to London (led by an inner voice) \\
\hline & & 6 & gets some strength in disorder and isolation \\
\hline & & 7 & goes to Pensionnat in Villette \\
\hline & & 8 & decides to be a teacher \\
\hline & & 9 & meets Ginevra \\
\hline \multirow{5}{*}{$\begin{array}{l}\text { intends to describe that Lucy tries to } \\
\text { conceal love for Graham (the fear to } \\
\text { be hurted) }\end{array}$} & conceals that John is Graham & 10 & meets Dr John \\
\hline & & 11 & sees Dr John talking to the portress \\
\hline & & 12 & the casket \\
\hline & & 13 & fails to hear whom John loves \\
\hline & & 14 & $\frac{\text { performs in a drama notices her passion but }}{\text { decides to conceal it }}$ \\
\hline \multirow[t]{4}{*}{$\begin{array}{l}\text { intends to describe that old Lucy } \\
\text { cannot overcome the past agonies }\end{array}$} & $\begin{array}{l}\text { the narration becomes rough with her } \\
\text { feelings }\end{array}$ & 15 & $\begin{array}{l}\text { the summer vacation isolation--the first } \\
\text { mental disorder }\end{array}$ \\
\hline & reveals readers that John is Graham & 16 & comes to herself at the Brettons \\
\hline & & 17 & subjects to the fate \\
\hline & & 18 & $\begin{array}{l}\text { stimulated by "Cleopatra" and "la vie d'une } \\
\text { femme" }\end{array}$ \\
\hline $\begin{array}{l}\text { intends to describe that old Lucy's } \\
\text { reason also subjects to her feelings }\end{array}$ & & 20 & the fete \\
\hline
\end{tabular}

\begin{tabular}{|c|c|c|c|}
\hline the implied atuhtor & the narrator (old Lucy) & $\mathrm{Ch}$. & young Lucy \\
\hline & & 21 & waits for John's letter (loses her reason) \\
\hline & & & Paul knows her passion \\
\hline & $\begin{array}{l}\text { draws readers into the plot by the present } \\
\text { tense }\end{array}$ & 22 & sees the nun \\
\hline & & 23 & sees Vashti and is impressed \\
\hline & & 24 & identifies Paulina \\
\hline \multirow[t]{3}{*}{$\begin{array}{l}\text { intendes to describe that Lucy } \\
\text { recovers the reason and conquers the } \\
\text { agony of lost love for John }\end{array}$} & & 25 & intercourse with John again \\
\hline & & 26 & decides to tackle the hard fate \\
\hline & & 27 & goes to the Hotel Crecy \\
\hline \multirow{9}{*}{$\begin{array}{l}\text { describes the passive attitude of old } \\
\text { Lucy for fear of being hurted }\end{array}$} & - conceals the love for Paul & 28 & makes a watch guard \\
\hline & shows the favor to Paul & 29 & gives a watch guard to Paul \\
\hline & & 30 & respects Paul's talent of art \\
\hline & show the favor to Paul (interior dialogues) & 31 & Paul and Lucy sees the nun \\
\hline & $\begin{array}{l}\text { has an uncomplicated view that } \\
\text { some people have fortunate fate }\end{array}$ & 32 & knows that John and Paulina love each other \\
\hline & shows the love for Paul & 33 & recognizes that she loves Paul \\
\hline & & 34 & knows the past of Paul \\
\hline & & 35 & be anxious about Paul \\
\hline & $\begin{array}{l}\text { draws readers into the plot by the present } \\
\text { tense }\end{array}$ & 36 & Paul leaves the school \\
\hline $\begin{array}{l}\text { intendes to describe that Lucy takes a } \\
\text { complete clear-cut attitude to the } \\
\text { couple }\end{array}$ & $\begin{array}{l}\text { narrates what have become of the two } \\
\text { calmly }\end{array}$ & 37 & \\
\hline
\end{tabular}




\section{Conclusion}

Villette's heroine and narrator is a new type of narrator who doubly functions as in the first-person and thirdperson. Such a narrator can handle both the first-person narration and the interior dialogues most effectively. The author created such a narrator to make it possible to describe the heroine's and narrator's consciousness and delineate her personality most freely. Insincerity, tense changes, and the break of the narrative-situation might seem like faults in the novel, but they actually represent a great success for the author.

It is normal for readers to identify with a hero or heroine in a novel. Thus, there is little need to examine emotional synchrony between young Lucy and readers. What makes this novel distinctive is emotional synchrony between its heroine and its narrator. The narrator, old Lucy, sometimes synchronizes with young Lucy and loses her calmness. Readers might find it frustrating to realize that they cannot rely on the narrator. They simultaneously, however, are drawn into synchronizing with the straightforward and openhearted narrator, who does not hesitate to express her emotions to readers. Consequently, the unique narrative of this novel leads

to an extraordinary form of emotional synchrony: between the narrator and readers. Blending of various kinds of synchrony made the novel too complicated and in chaos. It might be why this novel has not been valued as a masterpiece.

The implied author clearly makes a distinction between young Lucy and the narrator and precisely depicts the narrator's personality. The narrator does not live to 'die' like Miss Marchmont, but lives to 'live'. She tells her story with the intention of proving that. The implied author shows the human reality through Lucy's life to the implied readers behind the narratees. Thus, the real author also gives us, the real readers, a great impression and the courage to live our real life.

\section{References}

[1] W. S. Condon and L. W. Sander, Synchrony demonstrated between movements of the neonate and adult speech. Child Development, vol. 45, pp. 456-462. 1974. https://doi.org/10.1111/j.1467-8624.1974.tb00616.x

[2] K. L. Marsh, K. L., Richardson, M. J., and R. C. Schmidt, Social connection through joint action and interpersonal coordination. Topics in Cognitive Science, Vol 1, pp. 320-339. 2009.

https://doi.org/10.1111/j.1756-8765.2009.01022.x

[3] V. Gallase, M. N. Eagle, and P. Migone, International attunement: Mirror neurons and the neural underpinnings of interpersonal relations. Journal of the American Psychoanalytic Association, Vol. 50(1), pp. 131-175. 2007. https://doi.org/10.1177/00030651070550010601

[4] U. M. Ludtke, Emotion in Language. (Eds.) John Benjamins Publishing Company. 2015. https://doi.org/10.1075/ceb.10

[5] R. Pekrun, . R. Muis, A. C. Frenzel, and T. Goetz, Emotions at School. NY: Routledge. 2018. https://doi.org/10.4324/9781315187822

[6] C. Brontë, Villette, with an introduction by Tony Tanner, Penguin Classics. Harmondsworth: Penguin Books. 1979.

[7] N. Frye, S. Baker, and G. Perkins, The Harper Handbook to Literature. NY: Harper \& Row. 1985.

[8] M. H. Abrams, A Glossary of Literary Terms, 3rd ed. NY: Hold Rinehart and Winston, Inc. 1971.

[9] S. Chatman, Story and Discourse: Narrative Structure in Fiction and Film. Carnell University Press. 1986.

[10] S. Rimon, and Keran. Narrative Fiction: Contemporary Poetics. London: Methuen Inc. 1983.

[11] J. Carlisle, The Face in the Mirror: Villette and the Conceptions of Autobiography. E.L.H. Vol. 46, pp.262-289. 1979. https://doi.org/10.2307/2872615 
[12] B. R. Silver, The Reflecting Reader in Villette. In the Voyage in Fictions of Female Development, pp.90-111. ed. Abel, E., Hirsche, M. \& Langland, E. N.H.: University Press of New England for Dartmouth College. 1983. 